\title{
Evolution of Palaeozoic ammonoid sutures
}

\begin{abstract}
T.B. Leonova
Borissiak Paleontological Institute of the Russian Academy of Sciences. 123, Profsoyuznaya str., Moscow,117647, Russia.E-mail: tleon@paleo.ru
\end{abstract}

ABSTRACT. The history of the appearance and evolution of the suture, one of the major structural elements of the shells of ammonoids (a subclass of Cephalopoda), is briefly discussed. Its morphology is considered in the Devonian Anarcestida, the first members of which are very similar to the ancestral Bactritoidea, in the Late Devonian Clymeniida, the Devonian-Permian Tornoceratida, the Carboniferous-Permian Prolecanitida and Goniatitida, and the Permian Ceratitida. Three major trends in the evolution of the suture are recognized in the order Goniatitida, which were instrumental in the subdivision of this order into suborders. Variations of elements of the sutures allow the recognition of the familial, generic, and specific ranks.

How to cite this article: Leonova T.B. 2017. Evolution of Palaeozoic ammonoid sutures // Invert. Zool. Vol.14. No.1. P.27-31. doi: 10.15298/invertzool.14.1.05

KEY WORDS. Ammonoids, Paleozoic, evolution, sutures, systematics.

\section{Эволюция лопастных линий у палеозойских аммоноидей}

\section{Т.Б. Леонова}

Палеонтологический институт им. А.А.Борисяка РАН, Профсоюзная, 123, Москва, 117647 Poccuя.E-mail: tleon@paleo.ru

РЕЗЮМЕ: Кратко изложена история становления и развития в палеозое лопастной линии, одного из основных структурных элементов раковины аммоноидей (подкласса цефалопод). Показаны особенности ее строения у девонских Anarcestida, первые представители которых очень близки к своим предкам Bactritoidea, своеобразных позднедевонских Clymeniida, девонско-пермских Tornoceratida, каменноугольнопермских Prolecanitida и Goniatitida, пермских Ceratitida. В рамках отряда Goniatitida выделено три главных направления развития лопастной линии, которые находят свое выражение в подразделении отряда на три подотряда. Изменения отдельных элементов лопастной линии позволяют выделять таксоны семейственного, родового и видового ранга.

Как цитировать эту статью: Leonova T.B. 2017. Evolution of Palaeozoic ammonoid sutures // Invert. Zool. Vol.14. No.1. P.27-31. doi: 10.15298/invertzool.14.1.05

КЛЮЧЕВЫЕ СЛОВА: Аммоноидеи, палеозой, эволюция, лопастные линии. 

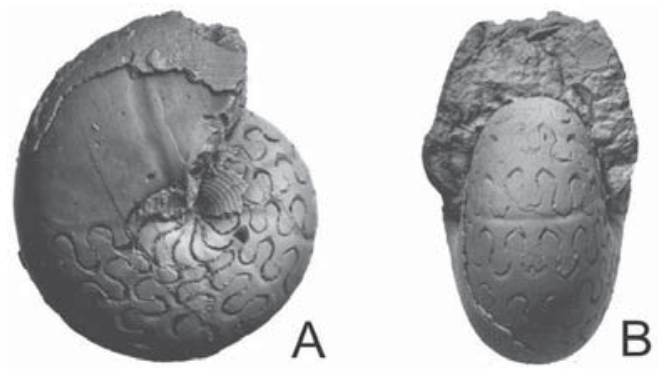

Fig. 1. A shell of Agathiceras mediterraneum Toumanskaya, 1949, Kungurian, Early Permian, showing a phragmocone (with sutures on its surface) and a body chamber.

A - lateral view; B - apertural view.

Рис. 1. Раковина Agathiceras mediterraneum Toumanskaya, 1949, кунгур, ранняя пермь. Видны фрагмокон (с лопастными линиями на поверхности) и жилая камера.

А - вид с боковой стороны; В - вид со стороны устья.

\section{Introduction}

The ammonoids appeared approximately 400 million years ago, at the end of the Early Devonian, and after 335 million years of evolution became extinct at the Mesozoic-Cenozoic boundary. For two hundred years they were used by palaeontologists as model objects to study morphogenesis and phylogeny. Their complexly organized shell retaining all ontogenetic stages allows reconstruction of phylogenies of groups of various systematic ranks.

The body plan of ammonoids includes three main morphological parameters: a coiled shell, a complex suture, and the presence of a protoconch. The ammonoid shell was subdivided into a body chamber (from 0.5 to 1.5 whorls) and a phragmocone working as a buoyancy device. Paleontologists usually study ammonoid sutures formed on the shell surface as an expression of the intersection of septa (Fig. 1). The sutures include lobes (expressions of curved surfaces directed adorally) separated by orally directed saddles. The lobes can be simple, serrated, festooned, etc., whereas the saddles are most frequently simply rounded. The sutural outlines are taxon-specific, and are used as the main diagnostic character for Paleozoic am- monoids. The general sutural outline is characteristic of orders and families, whereas its finer details are characteristic of genera and species. The development of a complexly curved septum and fluted dissected suture is the main trend in the evolution of Ammonoidea. The sutural ontogeny retained in the early whorls allows reliable reconstructions of the phylogeny of closely related taxa.

\section{Material and methods}

Despite the technological advances and the availability of micro-computed tomography, ammonoid sutures are mainly studied using a light microscope equipped with a drawing arm (camera lucida) to obtain graphic drawings (the method used for this study). These drawings were then scanned and print-ready copies were produced using graphics software, e.g., CorelDraw. The sutural outlines produced in this way were scaled, and then analyzed and compared. The elements of the sutures were designated using the terminology of Ruzhencev (1960). The study was based on the collections of Paleozoic ammonoids housed in the Borissiak Paleontological Institute, Russian Academy of Sciences, and on some previous literature sources.

\section{Results and Discussion}

The research of several generations of palaeontologists allows the evolution of the sutures to be traced in all Paleozoic orders. In very general terms, the results of this research can be summarized as follows. In the Emsian, at the end of the Early Devonian, representatives of the subclass Ammonoidea had a two-lobed suture inherited from bactritoids (designated by the formula VO, i.e., ventral and omnilateral lobes (covering the entire flank); these are the earliest ammonoid genera Anetoceras, Erbenoceras, Teicherticeras, etc. (order Anarcestida, family Anetoceratidae) (Fig. 2). The next stage is the appearance of a dorsal lobe (formula VO:D), which occurred at the end of the Emsian (genera Mimosphinctes, Talenticeras family Mimo- 


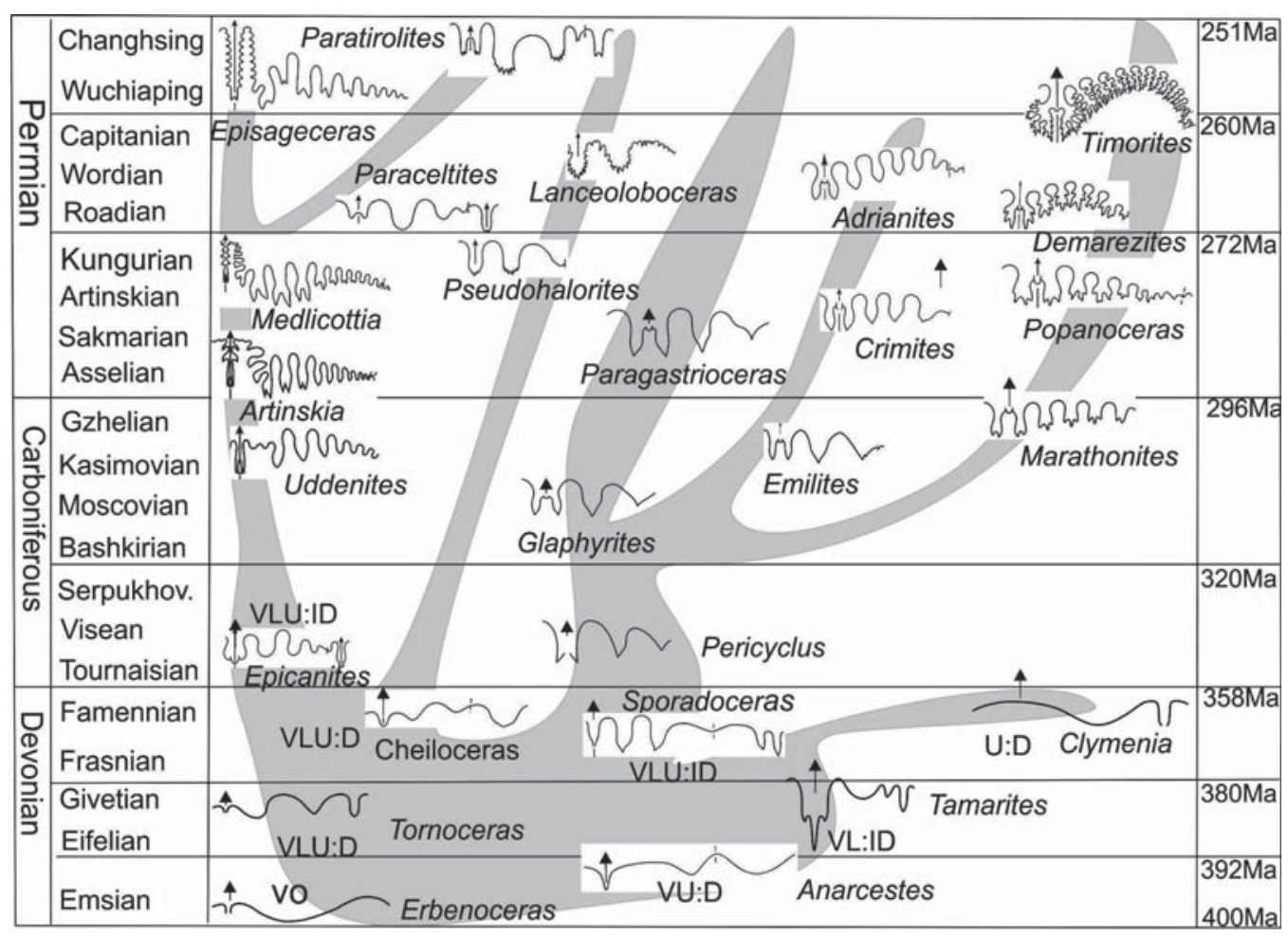

Fig. 2. Evolution of the Paleozoic ammonoid sutures.

Рис. 2. Эволюция лопастных линий аммоноидей в палеозое.

sphinctidae, etc.). At the very end of the Emsian, in the order Anarcestina (family Anarcestidae, genera Anarcestes, Cabrieroceras, Archoceras, etc.), the omnilateral lobe was replaced by the umbilical (U), the formula of the suture is VU:D (Fig. 2). In the Middle Devonian (Givetian), representatives of suborder Gephuroceratina (genus Tamarites, etc.) acquire the inner lateral lobe (I); such sutures are described by the formula VU:ID. The external lateral lobe (L) appeared in the Middle Devonian, when the four-lobed (VLU:D) order Tornoceratida (genus Tornoceras, etc.) appeared. In the Late Devonian (Famennian) five-lobed (VLU:ID) Sporadoceratidae (Sporadoceras, etc.) appeared (Fig. 2). All subsequent sutural modifications appeared on the basis of these five main lobes, which define the current system of the subclass Ammonoidea.

The suture type is defined by the morphology of primary suture formed by a rear mantle of the hatchling and by the morphology of several subsequent septa, in which the number and arrangement of lobes is considered to be fundamental for the definition of the body plan of the mollusk.

Almost the entire diversity of the septal margins (sutures) can be found among Anarcestida (Early Devonian, Emsian - end of the Devonian) known to exist in Paleozoic ammonoids, with the exception of the complexly subdivided sutures of the "Mesozoic type" that appeared at the end of the Paleozoic. For example, a broad, tripartite ventral lobe appeared in the Early Devonian in the suborder Auguritina. Later, in the Late Devonian, this character reappeared in the members of the suborder Gephuroceratina. In some Gephuroceratina, the suture was very complex due to the appearance of additional ventral or umbilical lobe (up to 54 lobes around a whorl). In members of the suborder Timanoceratina, the ventral lobe was bipar- 
tite. In general, most members of the oldest ammonoid order have the suture described by the sutural formula VU:D (Bogoslovsky, 1969).

Members of the order Clymeniida, which existed only for a very short time (the very end of the Devonian (Famennian)) were strikingly different from all other ammonoids. Instead of the ventral lobe they had a ventral saddle resulting from the dorsal, rather than the ventral, (as in most ammonoids) siphuncle (genus Clymenia, etc). Following the "archaic diversity" of the sutures of Devonian ammonoids assigned to the order Anarcestida with five suborders and Clymeniida with two suborders (Shevyrev, 2006), four large groups were formed by the beginning of the Carboniferous, each characterized by a particular evolutionary trend and receiving an ordinal rank.

The order Prolecanitida had previously been included in the Devonian order Agoniatitida (Ruzhencev, 1960; Bogoslovsky, 1969, etc.), because it was thought that in this order the most primitive suture consisted of three lobes VU:D. Studies of recent decades (Zakharov, 1984; Leonova and Voronov, 1989; Korn et al., 2002) showed that in prolecanitids the suture could be three-lobed (VU:D), four-lobed (VU:ID), and sometimes five-lobed (VLU:ID). In members of this order, the ventral lobe (V) was narrow, deep, tripartite, while the dorsal lobe was narrow and bipartite (genera Prolecanites, Epicanites, Pronorites, Medlicottia, etc). The main evolutionary trend in this order was manifested by increased complexity of the external saddle and of the number of lobes on the flanks up to 20 (Fig. 2). It is likely that this group of Paleozoic ammonoids gave rise to the Mesozoic Ceratitida at the Early-Middle Permian boundary.

The order Goniatitida (sensu Ruzhencev (1960), Bogoslovskaya et al. (1990), Bogoslovsky (1971) and other authors) is currently subdivided into three separate orders based on the mode of development of the ventral lobe (V): order Goniatitida (V - always bipartite), order Tornoceratida (V - in most cases undivided), and Praeglyphioceratida (V - broad and tripartite) (Leonova, 2002).

The order Goniatitida (Tournaisian-Changhsingian) includes three groups (suborders) rec- ognized based on the fundamental differences in the development of the primary lateral lobe (L) and umbilical (U) lobe: Goniatitina, Adrianitina, and Cyclolobina. In representatives of the suborder Goniatitina, the total number of lobes in the suture remained eight almost throughout their history (genera Glaphyrites, Paragastrioceras, etc), with the exception of some Schistoceratoidea (Carboniferous), with a suture in which the umbilical lobe U was further subdivided. In the majority of Goniatitina, the sutural complexity increased by altering the width and depth of main lobes, less commonly by development of teeth and projections on the main lobes, without forming new elements. The margins of the lobes and saddle usually remained entire. The two youngest families Metalegoceratidae (Early Permian) and Spirolegoceratidae (Middle Permian, Roadian) increase their sutural complexity throughout a division of the primary umbilical lobe. The most derived members of these families had a suture with 12-16 lobes. This increased complexity was achieved first by partial, then by complete subdivision of the umbilical lobe into three. It should be noted that in all ammonoid groups, the umbilical portion of the suture was the most mutable.

The second group, the suborder Adrianitina (Late Carboniferous, Kasimovian — Middle Permian, Capitanian) has a complex suture, which was formed in a very unusual way: unlike all other suborders, new umbilical lobes were formed at the top of the umbilical saddle and moved alternately first to the inner, and then to the outer sides of the whorl, following the formula $\left(\mathrm{V}_{1} \mathrm{~V}_{1}\right) \mathrm{LU}: \mathrm{ID} \rightarrow\left(\mathrm{V}_{1} \mathrm{~V}_{1}\right) \mathrm{LUU}^{2}: \mathrm{U}^{1} \mathrm{ID} \rightarrow$ $\left(\mathrm{V}_{1} \mathrm{~V}_{1}\right) \mathrm{LUU}^{2} \mathrm{U}^{\mathrm{n}+1}: \mathrm{U}^{\mathrm{n}} \mathrm{U}^{1} \mathrm{ID}$ (genera Emilites, Crimites, Adrianites, etc). Neither external, nor internal lateral lobes were subdivided. Margins of all lobes remained entire. This group branched off the Goniatitina by the beginning of the Late Carboniferous, but its main evolution was in the Permian (Fig. 2).

The most advanced goniatitids, representatives of the suborder Cyclolobina (late Carboniferous, Gzhelian — end of the Permian, Changhsingian), had the most complex sutures. Their sutures showed a primary subdivision of the 
lateral lobe following the formula $\mathrm{L} \rightarrow\left(\mathrm{L}_{2} \mathrm{~L}_{1} \mathrm{~L}_{2}\right)$ $\rightarrow \mathrm{L}_{2} \mathrm{~L}_{1} \mathrm{~L}_{2}$, and in some groups, a further subdivision of the third external lateral lobe. The inner lateral lobe (I) and umbilical (U) lobe in different superfamilies also underwent tripartite or bipartite subdivision and in different branches these changes followed different patterns. In addition, in all groups the lobes and saddles possess numerous digits and arches. This suborder includes the superfamilies with the most complex sutures (the total number of lobes in the suture reached 60): Cycloloboidea (genera Demarezites, Timorites, Cyclolobus, etc.), Shumarditoidea, Marathonitoidea (genus Marathonites, Cardiella, etc), and Popanoceratoidea (genus Popanoceras, Neopopanoceras, etc.) (Fig. 2).

The first Ceratitida appeared at the EarlyMiddle Permian boundary. Members of this, mainly Mesozoic order show a development from a three-lobed primary suture (in Middle Permian Paraceltitina, genus Paraceltites) VU:D to the five-lobed suture VLU:ID, and later the umbilical lobe disappears (VL:ID), while an additional inner lobe appears at later stages $\left(\mathrm{V}_{1} \mathrm{~V}_{1}\right) \mathrm{LII}^{1}$ : $\left(\mathrm{D}_{1} \mathrm{D}_{1}\right)$. Late Permian Paraceltitina have a fourlobed primary suture VL:ID (genera Paratirolites, Xenodiscus, etc) (Fig. 2). A further increase in complexity occurs with the development of new umbilical lobes $\left(\mathrm{V}_{1} \mathrm{~V}_{1}\right) \mathrm{LU}^{1} \mathrm{U}^{2}: \operatorname{II}\left(\mathrm{D}_{1} \mathrm{D}_{1}\right)$. This mode of increase in complexity marks a fundamental difference of Ceratitida from Prolecanitida and Goniatitida (Shevyrev, 1986).

More detailed changes in various elements of the ammonoid shell are usually taken into account in classifying taxa of lower taxonomic ranks: families, genera, and species. Usually Paleozoic ammonoids have a stable sutural pattern within the same taxon. Nevertheless, there are cases of asymmetrical development of lobes and saddles on different sides of the same shell, formation of additional digits and small lobes in the umbilical region(Leonova, 2016). The study of ammonoid sutures reveals cases of parallel development (synchronous and asynchronous), heterochronies, recapitulation, paedomorphosis, mosaic forms, which are all used in reconstructions of morphogenesis.
This is a brief history of the evolution of the Paleozoic ammonoid sutures, one of the major structural elements of the shell. It is evident that changes in the sutural outlines were controlled by a large system of organismal functions and communications, which maintained a certain stability and at the same time were initiated by external factors.

\section{Acknowledgements}

The study was supported by the Program No 28 of the Presidium of the Russian Academy of Sciences "Evolution of the Organic World and Planetary Processes" (subprogram 2).

\section{References}

Bogoslovskaya M.F., Mikhailova I.A., Shevyrev A.A. 1990. [System of ammonoids] // V.V. Menner (ed.). Sistema i filogeniya bespozvonochnykh. Moscow: Nauka. P.69-98 [in Russian].

Bogoslovsky B.I. 1969. [Devonian ammonoids. 1. Agonititida] // Trudy Paleontologicheskogo Instituta AN SSSR. Vol.124. 328 p. [in Russian].

Bogoslovsky B.I. 1971. [Devonian ammonoids. 2. Goniatitida] // Trudy Paleontologicheskogo Instituta AN SSSR. Vol.127. 228 p. [in Russian].

Korn D., Ebbighausen V., Bockwinkel J., Klug C. 2003. The A-mode sutural ontogeny in Prolecanitid ammonoids // Palaeontology. Vol.46. Part 6. P. 11231132 .

Leonova T.B. 2002. Permian ammonoids: Classification and Phylogeny // Paleontological Journal. Vol.36. Suppl.1. P. S1-S114.

Leonova T.B. 2016. Normal range and variation in the ontogeny of the Late Paleozoic ammonoid family Marathonitidae // Paleontological Journal. Vol.50. No.14. P.1579-1586.

Leonova T.B., Voronov A.V. 1989. Sutural ontogeny of the Early Permian ammonoid genus Synartinskia // Paleontologicheskii Zhurnal. No.1. P. $113-116$

Ruzhencev V.E. 1960. [Principles of systematics, system and phylogeny of Paleozoic ammonoids] // Trudy Paleontologicheskogo Instituta AN SSSR. Vol.33. 331 p. [in Russian].

Shevyrev A.A. 1986. [Triassic ammonoids] // Trudy Paleontologicheskogo Instituta AN SSSR. Vol.217. 184 p. [in Russian].

Shevyrev A.A. 2006. Macrosystem of cephalopods: historical review, current state and major problems. 3 . Classification of bactritoids and ammonoids // Paleontological Journal. Vol.40. No.2. P.34-46.

Zakharov Yu.D. 1984. [Ontogeny of Permian Pronoritidae and Medlicottiidae and the problem of the origin of ceratitids] // Sistematika i evolyutsiya bespozvonochnykh Dalnego Vostoka. Vladivostok: DVNTs AN SSSR. P.23-40 [in Russian].

Responsible editor E.N. Temereva 